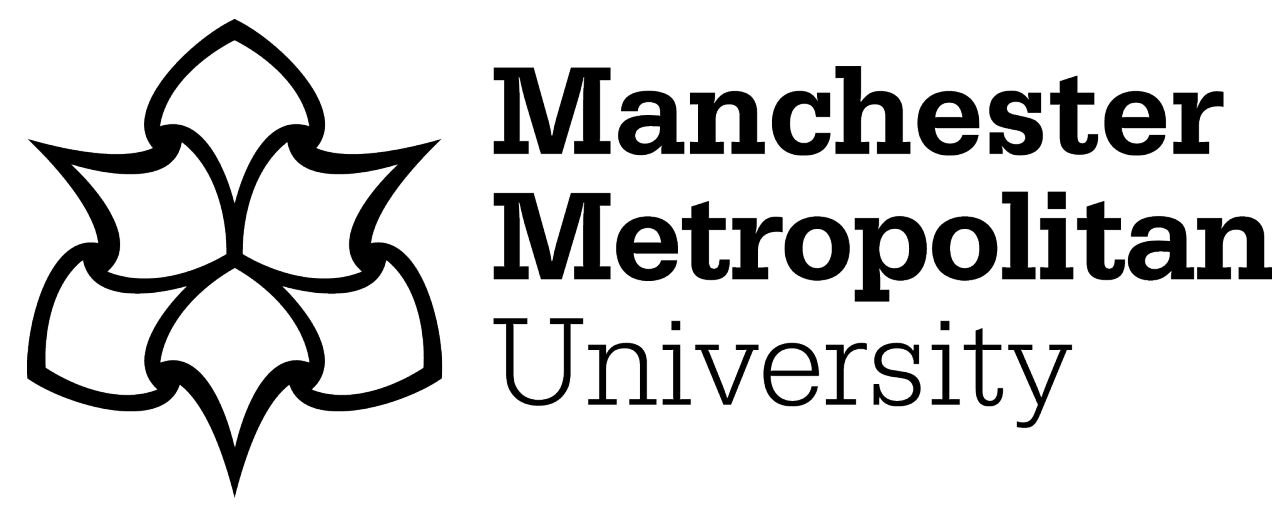

Giovanis, Eleftherios (2015) Relationship between happiness and income: evidence from panel smoothing transition regression in Great Britain. International Journal of Happiness and Development, 2 (4). pp. 346-370. ISSN 2049-2790

Downloaded from: https://e-space.mmu.ac.uk/620960/

Version: Accepted Version

Publisher: Inderscience

DOI: https://doi.org/10.1504/IJHD.2015.073943

Please cite the published version 


\section{Relationship between Happiness and Income: Evidence from Panel Smoothing Transition Regression (PSTR) in Great Britain}

\section{Eleftherios Giovanis}

University of Verona, Department of Economics, Via dell'Artigliere 8, 37129, Italy

Email: giovanis95@gmail.com

\section{Biographical Note}

Eleftherios Giovanis studied economics at the University of Thessaly. He completed the M.Sc. in applied economics and finance at the University of Macedonia, Greece and a second M.Sc. in quality assurance at the Hellenic Open University in Patra, Greece in 2009. He worked as statistician and econometrician analyst is marketing research companies. In December of 2014 he completed his Ph.d. in economics at Royal Holloway University of London. In 2013-2014 he worked as research collaborator in IMT Institute of Advanced Studies in Lucca, Italy, while currently now is individual Marie Sklodowska-Curie Research Fellow at University of Verona. 


\title{
Relationship between Happiness and Income: Evidence from Panel Smoothing Transition Regression (PSTR) in Great Britain
}

\begin{abstract}
The purpose of the paper is to test empirically the relationship between happiness, life satisfaction and income in Great Britain. The methodology followed is Panel Smoothing Transition (PSTR) models using the British Household Panel Survey (BHPS). The data period examined in the current study covers the period 1991-2009. Regarding the Logistic PSTR model the findings show that in the linear regime the association between household income, happiness and life satisfaction is insignificant. After some point the income has positive and significant effects on both subjective well-being measures. In the linear regime of the Exponential PSTR model the relationship between income and the happiness is positive; however after a specific level of income the association becomes negative. On the other hand, the Exponential PSTR model shows that the positive association between income and life satisfaction holds even for higher income levels. The originality of the paper is that Panel Smoothing Transition (PSTR) models based on micro-level household data have not been employed before, examining the non-linear relationship between income happiness and life satisfaction. Both Logistic and Exponential PSTR models are useful.
\end{abstract}

JEL codes: C23, D60, H41, I31

Keywords: Happiness; Life Satisfaction; Income; Smoothing Transition Functions 


\section{Introduction}

Life satisfaction measures how people evaluate their life as a whole rather than their current feelings. It captures a reflective assessment of which life circumstances and conditions are important for subjective well-being. Money can buy happiness because it can be exchanged for goods that will increase an individual's utility. Thus, money and happiness are assumed to be causally linked, and higher incomes should lead to greater happiness.

The correlation between money and happiness has been found to be often small, but effect sizes are larger in low-income developing economies (Howell and Howell, 2008), and even small correlations can reflect substantial real differences in happiness (Lucas and Schimmack, 2009). Such results, however, do not necessarily reflect a simple causal relation between money and happiness. The idea that absolute income leads to increased happiness is unable to account for the Easterlin's (1974) paradox-that income and happiness are positively associated within a country at a given time but not-or less well- correlated within a country over time.

A paradox in happiness research which has intrigued economists is that when a cross-section of the population is taken at any point in time, there is a clear positive relationship between income and subjective well-being. Yet since the Second World War mean reported levels of happiness have not risen despite the very large rises in real income. An obvious explanation is that of adaptation or habituation-the people questioned in later years are accustomed to higher material standards of living.

Thus, in many cases, substantial increases in wealth and income are not correlated with comparable increases in self-reported life satisfaction and happiness (Diener et al., 1985; Easterlin, 1974). However, recent analysis in a range of cross-country and within country data almost always finds a significant association between income and subjective well-being measures (Frijters et al., 2004; Giovanis, 2014). Frijters et al. (2004) found that the increase in 
peoples' incomes in East Germany led to large life satisfaction gains in the decade following the Reunification, while Frijters et al. (2006) found that the large swings in life satisfaction observed in post-transition Russia can be partially explained by variations in income. However, there are many exceptions, such as the study by Clark and Oswald (1994), who found an insignificant relationship between the General Health Questionnaire (GHQ), which is a mentalpsychological measure, and personal income in the BHPS dataset. Clark (2003) finds a negative relationship between personal income and GHQ which might be due to the costs of gaining the additional income, in terms of additional work hours and effort, while partner income and household income have positive effect. On the other hand, Shields and Wailoo (2002) and van den Berg and Ferrer-i-Carbonell (2005) found insignificant relationship between the logarithm of the household income and happiness. One explanation of these results is due the methodology approaches followed. For instance ordered Logit and Probit models are more appropriate; however, only random effects are allowed on panel data. On the other hand treating the ordinal life satisfaction and happiness variables as continuous are not enough to explain and examine the possible non-linear relationship between income and well-being. Thus, the abovementioned models cannot capture non-linearities and threshold effects.

The aim of this paper is the examination of the relationship between self-reported well-being and income using Panel Smoothing Transition Regressions (PSTR) based on individual-microlevel data derived by the British Household Panel Survey (BHPS). In addition, the non-linear relationship between happiness, life satisfaction and income has not been examined before using PSTR models. Furthermore, both PSTR models examined in this study are useful because they capture the non-linear dynamics in different thresholds which allow us to examine in more details these dynamics. This study shows that income has different effects on happiness and life satisfaction, as the former is a measure of an emotional state in the very short term, while the latter refers to the general satisfaction of life capturing the effects and individual's 
accomplishments in a long term period. The reasons why these differences are observed are discussed. The results show that for low income levels the relationship between income and the subjective well-being measures used in this study is insignificant, while it becomes positive when the household income reaches a specific level. Moreover, up to a household income level the association between happiness and income remains positive, while it becomes insignificant after an income level is passed. On the other hand a positive association between life satisfaction and income holds for higher income levels. Furthermore, the study suggests that the nonlinearity between income and well-being might be due to high inequalities in education, job status and income, which might have further negative effects on health and productivity among others. Finally, the study is based on rather high spatial level, which is the local authority district, allowing to control for time invariant unobserved area characteristics.

Other studies tried to examine the relationship and patterns between low-high satisfaction levels and income by applying latent class approaches, which account for slope heterogeneity (Clark et al., 2005; Becchetti et al. 2009). However, this study adds to the previous literature by proposing a panel threshold approach that allows us to assess the range of variation and the non-linear relationship between income and well-being measures (life satisfaction and happiness) while explaining individual heterogeneity and time variability. More specifically, this approach implies testing the existence of threshold effects in the relationship between the household income and well-being.

The structure of the paper is as follows: In section 2 the literature review is presented, while section 3 describes the methodology used in this study. Section 4 presents the data, and the research sample used in the analysis, while in section 5 the empirical results are reported and discussed. Finally, in the last section the concluding remarks are presented. 


\section{Literature Review}

There are numerous studies on happiness and well-being economics where life satisfaction has been examined in various cases, including job satisfaction, air pollution and climate.

Research studies on happiness have identified various personal, demographic and socioeconomic factors of happiness that explain observed happiness patterns. Some of the most important personal and demographic characteristics which affect happiness are age, sex, marital status, the size of the household and the education level (Di Tella et al., 2003; Pischke, 2011). Sandvik et al. (1993) have shown that respondents who are satisfied with their lives are also rated as satisfied by family members and friends. Blanchflower and Oswald (2007) found that satisfied individuals are less likely to suffer from hypertension. Economic conditions like income, unemployment have also a strong impact on people's subjective well-being (Clark and Oswald, 1994; Easterlin, 2001). Furthermore, life satisfaction predicts future marriage and future marital break-up (Gardner and Oswald, 2006; Stutzer and Frey, 2006).

Regarding climate and weather both calendar effects and weather affect life satisfaction; see for example Brereton et al. (2008) for the effect of wind speed, temperature and pollution. These studies are related with climate and life satisfaction (Frijters and van Praag, 1998). More precisely, the authors found that if temperature rose by one degree, inhabitants of Moscow would need $13.5 \%$ less income to maintain the same welfare level.

Finally, life satisfaction and self-reported well-being has been examined for the air pollution. The LSE has been used by Welsh $(2006 ; 2007)$ to evaluate environmental factors. More precisely, Welsch $(2006 ; 2007)$, examines average life satisfaction in relation to average air pollution values across countries and he finds significant negative associations in each case. Rehdanz and Maddison (2008) find that perceived levels of air pollution are also negatively related to life satisfaction scores in Germany using information about how strongly the 
respondent feels affected by air and noise pollution in their place of residence. A similar research by Giovanis (2012) investigated the environmental Kuznets curve (EKC), using Panel Smoothing Transition Regressions (PSTR) in the city of London. More specifically, sulphur dioxide $\left(\mathrm{SO}_{2}\right)$ and carbon monoxide $(\mathrm{CO})$ are examined. The relationship between income and air pollution is negative in the low and high income classes, while it becomes positive for the middle income class.

More recent studies however, show that income can be associated negatively to happiness and life satisfaction. Kahneman and Deaton (2010) using a survey of 450,000 individuals in USA during 2008-2009, found that low life satisfaction and low emotional well-being (happiness) are associated with low income. Also they show that happiness and life satisfaction are increased with income, while high income buys life satisfaction but not happiness, as after $\$ 75,000$ the income has no effects on the latter. In addition, high and low income classes are less happy than middle income classes. Mayraz et al. (2009) claim that it is important to consider the role of peers and of reference group income on an individual's happiness and life satisfaction. Becchetti et al. (2009) using the BHPS dataset found that a negative relationship is presented between income and happiness sub-sample" called as "frustrated achievers". Moreover, they found that the probability of belonging to such group is shown to be positively related with divorced status and negatively related to education and relative-personal to reference group- income.

Generally, the motivation of this study is that the non-linear association between income and subjective well-being measures is explored using a rich panel dataset in Britain. Moreover, previous researches either ignored this non-linear relationship or they found only significant monotonic relationship suggesting that the quadratic terms of income are insignificant (Brereton et al., 2008; Rehdanz and Maddison, 2008; Chevalier and Giovanis, 2012; Giovanis, 
2014). This might due the fact that they add only quadratic terms and estimating using ordinary least squares.

\section{Methodology}

\subsection{Panel Smoothing Transition (PSTR) model}

The methodology followed in this study is similar to Aslanidis and Xepapadea's (2008) paper. The difference is that this paper uses a Panel Smoothing Transition (PSTR) referring to micro-level data and not macroeconomic data, as countries. Based on STAR model methodology (Granger and Terasvirta, 1993; Terasvirta, 1994; van Dijk et al., 2002) a Panel Smoothing Transition Regression (PSTR) has been proposed by Gonzalez et al. (2005). The PSTR model used in this study is:

$$
L S_{i t}=\mu_{i}+\beta^{\prime}{ }_{0} \mathrm{x}_{i, t}+\beta_{1}^{\prime} \mathrm{x}_{i, t} G\left(y_{i t} ; \gamma, c\right)+\varepsilon_{i t}
$$

, where, $L S_{i t}$ denotes the life satisfaction or happiness for individual $i$ and time $t, y$ is the personal or household income, $x_{i t}$ is a $k$-vector containing the independent variables; the income and control variables, $\mu_{i}$ represents the individual fixed effects and $\varepsilon_{i t}$ is the error term. The transition function $G\left(y_{i t} ; \gamma, c\right)$ is a continuous function of the observable variable $y_{i t}$ and is normalised to be bounded between 0 and 1. These extreme values are associated with coefficients $\beta_{0}$ and $\beta_{0}+\beta_{1}$ respectively. Two transition functions are examined; the logistic and the exponential. These functions can be expressed by relation (2) and (3) respectively.

$$
\begin{aligned}
& G\left(y_{i, t} ; \gamma ; c\right)=\left(1+\exp \left(-\gamma \prod_{j=1}^{P}\left(\log \left(y_{i, t-j}\right)-c\right)\right)^{-1}\right. \\
& G\left(y_{i, t} ; \gamma ; c\right)=1-\exp \left(-\gamma \prod_{j=1}^{P}\left(\log \left(y_{i, t-j}\right)-c\right)^{2}\right)
\end{aligned}
$$


, with parameter $\gamma>0$. For relations (2) and (3) the following interpretation is possible. In the inner regime the individuals or households with low-middle income are included, while the individuals or households belonging in the high income class are expressed by the outer regime, which is characterised by the respective transition function. The parameter $c$ can be interpreted as the threshold between the two regimes, in the sense that the transition function changes monotonically from 0 to 1 as the transition variable $y_{i t}$ increases. The parameter $\gamma$ determines the smoothness of the transition from one regime to the other.

\subsection{Parameter estimation}

Estimating the parameters in the PSTR model (1) is an application of the fixed effects estimator and non-linear least squares (NLS). NLS are applied for the values determination of these parameters that minimise the concentrated sum of squared errors. These are defined as:

$$
\operatorname{SSE}(\gamma, c)=\sum_{i=1}^{N} \sum_{t=1}^{T}\left(\tilde{\mathrm{LS}_{i, t}}-\tilde{\hat{\beta}}\left(\gamma, c^{\prime}\right) \mathrm{x}_{i, t}(\gamma, c)\right)
$$

, where $\hat{\beta}\left(\gamma, c^{\prime}\right)$ is obtained from (1) by ordinary least squares (OLS) at each iteration. The null hypothesis of linearity is $H_{0}: \gamma=0$, which expresses no regime-switching effect in the data. Gonzalez et al. (2005) develop the parameter constancy test. This is done using the alternative that the parameters in (1) change smoothly over time. The model under the alternative is time varying PSTR. If $p=1$ in (2)-(3), then the alternative is defined as:

$$
e_{i t}=\mu_{i}+\sum_{j=1}^{2} f_{j}\left(\gamma_{2} ; c_{2}\right) *\left(\beta^{\prime} \mathrm{x}_{i, t}\left(\gamma_{1} ; c_{1}\right)\right)+u_{i, t}
$$

, where $f_{1}()=$.1 and $f_{2}($.$) is as given by (2)-(3). If the parameter \gamma_{2}=0$ this reduces to (1) and indicates parameter constancy. 


\subsection{Regressions with ordered variables}

In its current form the model cannot be estimated by ordered probit or logit using fixed effects. Therefore there are two options, either by estimating the model converting the dependent ordinal variable in continuous variable assigning z-scores. The last procedure was introduced by van Praag and Ferrer-i-Carbonell (2004) where the new dependent variable takes the conditional mean-given the original ordinal rating- of a standardised normally-distributed continuous variable, calculated based on the frequencies of the ordinal ratings in the sample.

In addition, household income is included into the regression analysis and treat it as a moderating variable in various dimensions. More specifically, let us assume that we have a general regression which examines how the $X-Y$ relations varies.

$$
Y=b_{o}+b_{1} X+b_{2} Z+b_{3} X Z+u
$$

In this case $Y$ denotes happiness, $X$ is the education level and $Z$ is the moderating variable, and specifically income and $u$ is the disturbance term. Thus, if the coefficient $b_{3}$ is statistically significant, it suggests that $Z$ (income) modifies the $X-Y$ (education-happiness) relation. In this study the income is examined in various dimensions with the control variables, such as education level, job status, health status, house tenure and marital status.

\section{Data}

We use the British Household Panel Survey (BHPS) an annual survey of each adult member of a nationally representative which started in 1991. The data period examined in the current study covers the waves 1-18 ie. years 1991-2009. The British Household Panel Survey is being 
carried out by the Economic and Social Research Council (ESRC) United Kingdom (UK) Longitudinal Studies Centre with the Institute for Social and Economic Research at the University of Essex. The main objective of the survey is to further understand the social and economic change at the individual and household level in Britain, to identify, model and forecast such changes, their causes and consequences in relation to a range of socio-economic variables.

The BHPS has been extensively used for empirical work on life satisfaction - happiness (Clark and Oswald, 1994; Giovanis, 2014). Regressions control for demographic and household variables as gender, age, age squared, household size, job status, house tenure, marital status, health status, education level and local authority districts. Additionally, the regressions control for the day of the week, month of the year and the wave of the survey, while standard errors are clustered on local authority district level.

The survey contains a question about happiness. General happiness is an ordinal variable measured on a 4-point scale and the specific phrasing of the question is the following "Have you recently been feeling reasonably happy, all things considered". The second variable considered is a question whether the respondent is unhappy or depressed, measured on a 4-point scale from 1 (much more unhappy) to 4 (not at all). The third variable is whether the respondent enjoys the day to day activities measured again on a 4-point scale from 1 (much less than usual) to 4 (more so than usual). Regarding the life satisfaction the question asks the respondent to evaluate his overall life satisfaction in a scale from 1 (not satisfied at all) to 7 (totally satisfied). Regarding income, the annual household income is considered, as the results and conclusions, taking the monthly household income, are almost identical, showing that there is no measurement error between these two variables.

The reliability of life satisfaction and happiness scales are important because they reveal that over short intervals, when most peoples' lives are unlikely to have changed substantially, 
similar levels of evaluation are reported. Although peoples' moods are likely to differ substantially across short periods of time (Diener and Larsen, 1984), life evaluation judgments are relatively stable across short time intervals in most survey settings.

Life satisfaction has been analysed in many previous researches over time in large data sets from Germany (SOEP), the United Kingdom (BHPS) and Australia (HILDA) (Lucas et al., 2003; Lucas and Clark, 2006; Lucas, 2007) indicating that life satisfaction and happiness are valid and reliable measures of subjective well-being. These studies found that people tend to react as expected to conditions, such as marital status, assault, disability, job status, like unemployment, and childbirth with increases or decreases in their life satisfaction and happiness. For some conditions such as marriage the adaptation was complete, whereas for other conditions such as unemployment and severe disability people did not fully adapt even after many years. These patterns of life satisfaction scores show the sensitivity of the measures to change, as well as, they indicate the validity of the scales and items to mirror important life changes that would be expected to affect peoples' well-being. Rattray and Jones (2007) argue that using a single item for happiness is an issue. For this reason, the items enjoy the day-today activities and unhappiness are obtained as robustness checks, creating a well-being score combining the two items. We will refer to this new variable as depress and enjoyment with daily activities.

Next the reliability and validity of the depress and enjoyment with daily activities is examined. Cronbach's $\alpha$ is a common statistic used to test reliability. However, there are issues with this statistic, as it should be treated with caution when $\alpha$ has been computed from items that are not correlated. Also $\alpha$ depends on the magnitude of the correlations among items, but also on the number of items in the scale. Thus, a scale might look more "homogenous" if the number of items are doubled and the average correlation remains the same. This leads to another problem, which is the case where if two scales are used to measure a distinct aspect and combine 
them to form one long scale then $\alpha$ would be high. In table 1 the Cronbach's $\alpha$ equal at 0.8754 , higher than the rule of thumb, which is 0.75 , confirming the reliability of the depress and enjoyment with daily activities index. In addition, the Composite Reliability (CR) index proposed by Fornell and Larcker, 1981), which is defined as the ratio of the sum of factor loadings over the sum of factor loadings plus the sum of the error variance associated with the individual indicator variables is estimated. The CR is defined as:

$$
C R=\frac{\left(\sum_{i=1}^{p} \lambda_{y i}\right)^{2}}{\left(\sum_{i=1}^{p} \lambda_{y i}\right)^{2}+\sum_{i=1}^{p} \operatorname{Var}\left(\varepsilon_{i}\right)}
$$

This index provides much more precise estimates than Cronbach's $\alpha$ and the estimated CR index is presented in table 1 and it is equal at 0.794 . This is higher than the proposed threshold of 0.7 , confirming the reliability of the depress and enjoyment with daily activities constructed variable. The average variance extracted (AVE) is used to test the convergent validity which is defined similarly to $\mathrm{CR}$ with the only difference that the sum of sum of squared factor loadings is considered. The index is equal at 0.6893 higher than 0.5 indicating that there are no validity issues. Concluding the variables are well correlated each other within their parent factor; thus the latent factor is well explained by the observed variables.

The next approach followed in order to examine the reliability and validity of the well-being measures is the confirmatory factor analysis (CFA) similar to other studies suggested by Rattray and Jones (2007). Reliability refers to the stability and the internal consistency of a questionnaire and/or item (Jack and Clarke, 1998). CFA is used, in order to study how well a hypothesised factor model fits a new sample from the same population. CFA allows us to study the properties of individuals by examining factor variances, and covariances, where the factor variances show the heterogeneity in a population, while the factor correlations show the strength 
of the association between factors. The model fit evaluation is based on three goodness-of-fit indices; comparative fit index (CFI), Tucker-Lewis index (TLI) and the root mean square error of approximation (RMSEA) According to Hu and Bentler (1999), a CFI and TLI value of greater than 0.90 can be expected for a very good fit to the data. As a rule of thumb, if the value of RMSEA is lower than 0.05 indicates a good fit, values between 0.05-0.08 suggest acceptable fit, while values higher than 0.10 imply poor model fit (Hancock and Mueller, 2006). The last index is the root mean square residual (RMSR), which is a measure of the mean absolute value of the covariance residuals. Generally, values less than 0.1 indicate good estimates. In table 1 the goodness of fit statistics are reported, where CFI and TLI are very close to 1, the RMSEA is much below 0.05 , while RMSR is equal at 0.0002 much lower than the suggested value of 0.1. Overall, the results reported in table 1 indicate the reliability and validity of the depress and enjoyment with daily activities variable.

(Insert table 1)

One of the most important and unique characteristics of BHPS is its longitudinal structure which allow us to follow the individuals and the inclusion of their history into a fixed effects model. In addition, the sample includes all adult household members, as well as young people aged 11 to 15, providing more accurate household level information than it would be in the case where only one individual in each household is interviewed. Furthermore, this long accumulation of life history data collected in the early waves, makes the dataset unique and suited for analysis of long term accumulation of factors, such as personal and financial, and their impact on later outcomes, including education and labour outcomes. Finally, BHPS allows for comparative longitudinal analysis of different component and geographical parts of the UK.

One the other hand, one of the main limitations of BHPS is the fact that it suffers from the typical panel data problems like attrition and non-response. Another important drawback is that 
full life history records are only complete for BHPS respondents who were interviewed at waves 1-2. Therefore, for the new adult entrants to the BHPS, such as those incorporated by the extension samples- from Scotland and Wales at wave 9 (1999) and Northern Ireland at wave 11 (2001)- the full life history information is unavailable for them. Additionally, Crouchley and Oskrocki (2001) have argued that the representativeness of the BHPS's life history records is seriously compromised by several endogeneous sample selection effects.

However, whilst BHPS has its limitations it is one of the only data source which enable the researchers to examine in more details the dynamics of life satisfaction, happiness and income and their relationships with personal and demographic characteristics and non-market goods, such as air quality.

\section{Empirical Results}

In table 2 the non-linearity LM test proposed by Luukkonen et al. (1988) is reported. The LM-type test is given by $\mathrm{LM}=\mathrm{TN}\left[\left(\mathrm{RSS}_{0}-\mathrm{RSS}_{1}\right) / \mathrm{RSS}_{0}\right]$, where $R S S_{0}$ represents respectively the residual sum of squares of the linear panel model, while $R S S_{1}$ is derived by the auxiliary regression. The LM test follows the $x^{2}{ }_{k}$ distribution, where $k$ is the number of regressors. Based on that, the null hypothesis of linearity is rejected regarding the three well-being measures examined.

In table 3 the Logistic and exponential PSTR results are reported. It should be noticed that the observations vary between happiness measures (general happiness and depressionenjoyment with daily activities) and life satisfaction regressions, because happiness measures are available since the first wave of the BHPS, while life satisfaction became available after the $6^{\text {th }}$ wave. Generally, both coefficients $\beta_{0}$ and $\beta_{l}$, are significant, with the exception the coefficient $\beta_{0}$ and the Logistic PSTR model. Furthermore, the threshold parameter $c$ and the 
slope parameter $\gamma$ are significant in all cases. The slope parameter $\gamma$, which shows the speed between extreme regimes, presents low values ranging between 0.9-1.3, implying a rather slow transition.

(Insert tables 2-3)

Threshold $c$ shows the value where the transition takes place. Regarding Logistic PSTR results the relationship between income and happiness is negative, but statistically insignificant, in the linear regime and up to an income threshold equal at $£ 19,200$ per year. After this point the relationship between income and happiness in the non-linear regime is positive. Thus, happiness increases significantly with income after the threshold of $£ 19,200$. Similarly, the relationship between depression and enjoyment with daily activities and income is insignificant, in the linear regime up to a point of income threshold equal at $£ 14,500$. Considering the power parity of income the value of $£ 19,200$ is equivalent at $£ 13,200$ during the period 1991-1993, $£ 15,000$ during the years $1998-2001$ and $£ 18,000$ during the period 2002-2004. Similarly, $£ 14,500$ is equivalent at $£ 10,000$ during the years $1991-1995, £ 12,500$ during the period 19962000 and $£ 13,000$ during 2001-2003.

In parallel with Logistic PSTR results, the findings derived by the exponential PSTR are used as supplement. More specifically, the relationship between general happiness and income is positive and significant in the linear regime, while after a certain point of household income, where threshold $c$ is equal at $£ 113,000$ per year, the relationship becomes negative in the nonlinear regime. Similarly, the relationship between depression and enjoyment with daily activities and income is positive, while it becomes negative for values more than $£ 109,000$ per year. Thus, the conclusion is that an income higher than $£ 113,000$ and $£ 109,000$ does not buy more happiness. However, this does not imply that $£ 113,000$ will have indifferent impact in the period examined between the years 1991-2009. Controlling for the power parity of income the 
changes on income are presented in table 4. More specifically, an income higher than $£ 113,000$ does not buy more happiness which is equivalent to $£ 74,000$ in $1991, £ 85,000$ in 1996 and $£ 100,000$ in 2004-2005.

Regarding life satisfaction the conclusions are similar when Logistic PSTR is considered. More specifically, based on the Logistic PSTR estimates in the first panel of table 3 the income has insignificant effects in the linear regime. When the transition takes place, which is equal at $£ 26,700$ per year, then the income has positive effects on life satisfaction. On the other hand, Exponential PSTR model shows that the relationship between income and life satisfaction holds even for high income levels. Concerning the different effects of income and the two subjective well-being measures used in this study there are various explanations which are discussed later in this section.

Using the Wald statistic and based on the p-values, the sum of the coefficients $\beta_{0}+\beta_{1}$ is significant and positive in the case of the logistic PSTR indicating the positive effects of income on happiness and life satisfaction, as reported previously, when the transition function is 1 . Similarly, regarding the exponential PSTR the sum of the coefficients $\beta_{0}+\beta_{1}$ is significant in all estimates and negative indicating the negative effects of income on happiness and depression after some point of the income threshold, while the positive sum of the coefficients $\beta_{0}+\beta_{1}$ shows the continuous positive effects of income on life satisfaction.

\section{(Insert table 4)}

Further insight into the non-linear dynamics can be obtained from the figures 1-6, which display the transition functions. More specifically, in figures 1-3 the curve for $\alpha_{1}+G(\cdot) \beta_{1}$ derived by logistic PSTR model is presented, along with its confidence intervals represented by the grey lines, respectively for happiness, depression and enjoyment with daily activities and life satisfaction. Similarly, the curve for $\alpha_{1}+G(\cdot) \beta_{1}$ using the exponential PSTR model is 
presented in figures 4-6 for the three subjective well-being measures. In figures 1-6 the vertical lines are approximate bands where $G(\cdot) \approx 0$ and $G(\cdot) \approx 1$.

\section{(Insert figures 1-6)}

Therefore after a threshold in the household income, happiness is constrained by other factors in individual's temperament and life circumstances. According to Cummins (2012), money is a significant determinant; however it cannot shift the set-point to create a perpetually happier person. Thus, in this point of view money cannot buy happiness. Concluding the results show that income increase has the following effects on happiness. Firstly, there is a direct effect, as the additional income increases the opportunities of choices in the market; greater opportunities of health education and comfort among others resulting in increases in subjective well-being. The indirect effect is that increases in income interfere with other areas of life including relational goods, which are goods that cannot be enjoyed alone (Uhlaner, 1989). Therefore, very high income carries a high weight on unhappiness because it reduces the time for gratuitousness and for intrinsically motivated activities. In plain words in lower income levels further increases of income are not enough to buy happiness until income reaches a certain threshold. On the other hand on high income levels, after a threshold on income, money does not buy anymore happiness, meaning that there are other factors which can increase and improve the subjective well-being such as relational goods.

For example based on the BHPS data, the percentage of individuals who self-reported that they are less happy and those who reported same level of happiness is 10.41 and 71.88 per cent respectively having an annual household income between $£ 30,000$ and $£ 120,000$. For individuals having an annual household income more than $£ 120,000,11.60$ per cent reported lower levels of happiness, while the 68.00 per cent reported the same happiness level as before. 
Other explanations about the results are psychological. Firstly, this is related to the comparison income ie. the income of the partner, colleague, friend of the individual, where in the case that the individual has a lower income than the other's incomes it makes him less happy. Secondly, not only income but also relational goods and relationships make people happier. Thus, individuals with very high income might have fewer relationships. However, this is very difficult to be quantified in an economic study, and this might be answered more properly by other sciences, including psychology and sociology. Thirdly, in most cases high income is related with additional hours of work, which might make people less happy. Fourthly, the richer individuals usually have achieved all material goals and they might ask themselves what is left after that. However, the income is associated positively with the life satisfaction. This can be explained from the fact that people with high income have accomplished many things or they have successful careers and income helps them to achieve these; however it is not implied that income can buy more happiness.

The results are consistent with the study by Becchetti et al. (2009). More specifically, the insignificant relationship between income and happiness-life satisfaction is referred on individuals with low education level, who are mainly unemployed, retired, low wage employed and who are housekeepers (family care). More specifically, based on the Logistic results, the percentage of the individuals who are retired belonging below the annual household income of $£ 19,200$, is 74 per cent, while the percentage for the employed, unemployed and housekeepers is $18.00,64.00$ and 41.00 per cent respectively. Regarding education and household income classes below the $£ 19,200$ annually threshold; $11.00,15.10$ and 61.35 per cent of the sample holds respectively a higher degree, a first degree and no qualification. Moreover, the low income class sample belongs to the lowest 25 percentile which indicates the high inequalities regarding life satisfaction and happiness in UK society assuming that BHPS represents the demographic characteristics of the UK national population. Moreover, the low threshold values 
found in the analysis might be explained by those high inequalities. In other words, considering only the high versus the low income classes, different patterns might be revealed. This can be investigated by applying latent class approaches, which account for slope heterogeneity. However, this has been examined by Clark et al. (2005) and Becchetti et al. (2009). Finally, the higher income threshold observed for life satisfaction, in comparison with happiness, might be probably explained by the fact that individuals need a higher income to remain satisfied.

In line with the previous findings, the results taking income as a moderating variable are reported in table 3. The interaction of income with single, widowed and divorced individuals is positive indicating that these individuals are more likely to report higher levels of happiness and life satisfaction rises on income than the married respondents, which is the reference category. This indicates that income is a more important factor for happiness in these groups, as they belong to lower income classes as it has been discussed previously. Similarly, income rises is associated with higher levels of well-being for unemployed and retired than the employed individuals. The effects are stronger for unemployed, regarding general happiness and life satisfaction; however, in the case of depression and enjoyment with daily activities income becomes more important for retired. Similar conclusions are derived for education level, where individuals who completed education at A level are happier with rises on income than those who completed a higher postgraduate degree. Finally, those who have poor and very good health status are more likely to report lower levels of well-being with rises on income than those with very poor health status (reference category). This can be expected, as income might have much more importance and weight for people who report very poor health status (versus those with poor and very good health status). This can be associated with physical diseases which require an important amount of money or mental diseases, where unemployed, widowed and poor individual might suffer from. In addition, married people are also healthier. In addition, it is possible that satisfied individuals are more likely to get or remain married than 
less satisfied people, as the former may have more attractive personalities (Gove et al., 1990; Zimmermann and Easterlin, 2006).

The results slightly change when health status is excluded from the analysis. This case is examined because there might be an inverse causality between self-reported well-being and health status. Similarly, there is evidence of negative correlation between happiness and unemployment. However, inverse causality might run in the opposite direction; unhappy people do not perform well. So the question of reverse causality due to selection bias has been analysed in many studies with longitudinal data, before and after particular workers loses their jobs. There is evidence that unhappy people do not perform well on the labour market, but the main causality seems clearly to run from unemployment to unhappiness (Winkelmann and Winkelmann, 1998; Marks and Fleming, 1999).

In addition, the residuals sum of squares (RSS), the Akaike (AIC) and Bayesian information criterion (BIC) are reported. AIC and BIC information criteria are calculated based on the likelihood function; thus they are not comparable for the regressions between happiness, depression and enjoyment with daily activities and life satisfaction due to the different number of observations which are used for the likelihood function calculation. Also the Lagrange Multiplier (LM) test for no remaining non-linearity proposed by Eitrheim and Teräsvirta (1996) is reported in table 3. Based on the p-values the null hypothesis of no remaining non-linearity is accepted.

In tables 5-6 the estimated coefficients for the control variables regarding Logistic and Exponential PSTR models are reported. Regarding age, a U-shaped curve is found with a turning point ranging between $39-46$ years old. The widowed and divorced individuals report lower levels of happiness and life satisfaction than the married individuals which is the reference category. On the other hand being single has no difference on happiness; however, the effect becomes negative when life satisfaction is considered. Being employed has no 
difference in comparison with self-employees, while unemployed and retired individuals are less happy and less satisfied with their lives as it was expected. Education level is another important factor of happiness, as individuals who hold A level are less happy than individuals who completed higher education. In addition, there is no difference on well-being by either having a teaching qualification or a higher university degree, while the former has negative effects when life satisfaction is considered. These results show the main difference between happiness and life satisfaction. While the latter implies for someone being content and acceptable, sufficient and adequate, happiness is a positive feeling or state of well-being. Thus, the difference on being satisfied with life is more about meeting or accomplishing an expectation where there is a standard and someone defines how close or not from meeting it is, whereas, at least in theory, there are no upper limits to happiness. Finally, as it was expected, the individuals with very poor self-reported health status are much less satisfaction and less happy than respondents with very good health, which is the reference category

Concerning the meteorological data, well-being rises with average temperature, precipitation and with the difference between the daily maximum and minimum, which proxies for cloud cover or humidity. Finally, wind speed has no effects on either happiness or life satisfaction. Overall the results are consistent with other studies (Clark and Oswald, 1994; Giovanis, 2014).

\section{(Insert tables 5-6)}

However, there are important limitations in this study. Firstly, the data sample is based in UK which is a developed and English speaking country. Therefore, the results might not be global and there might be similarities only among developed English speaking countries, such as Canada, USA and Australia among others. Secondly, the analysis is based on the whole sample of BHPS. In other words, there might be differences not only between countries, but 
also within a country. Individuals interviewed in the BHPS sample examined in this study come from one country, therefore solving potential cultural biases in reported happiness and life satisfaction generated by inter-country analysis. However, even if regressions control for local authority districts, there might be differences across regions, which might not be captured by the modeling followed in this study. Thus, different sub-samples, such as regions, gender, urban and rural areas can be examined for future research. Thirdly, total wealth or comparison income instead of income might be more proper measures for life satisfaction. Lastly, another major limit of this study is the potential endogeneity and reverse causality between well-being and income. More specifically, while household income might have causal effects on life satisfaction and happiness, happier and more satisfied individuals might earn more. In order to test for weak exogeneity a multivariate non-linear framework as in Jansen and Terasvirta (1996) it is necessary to be considered. However, even a single equation non-linear model may lack efficiency in the case where the weak exogeneity does not hold, it has the advantage of avoiding the specification of additional non-linear equations. Nevertheless, instrumental variable methods are not actually available in a non-linear panel context.

\section{Conclusions}

This paper examined PSTR for happiness/life satisfaction and income. The methodology of smooth transition regression allows for continuous smooth changes in regimes, which lead to a very good modelling of structural breaks, asymmetries in dynamics of variables, and many other applications. Additionally, the methodology easily incorporates the possibility of regime reversals. Numerous fruitful applications have been found for smooth transition regression models in economics, ranging from modelling exchange rate dynamics and asymmetries in sectoral wage structure and non-linear disaggregated models of business cycles. 
The assessment of this study is based on the estimation of various threshold panel specifications of income. The main results can be summarised in two main points. First, the relationship between the income and the well-being measures examined in this study is nonlinear. More precisely, strong threshold effects can be identified in these relationships. The association between income and happiness is positive; however after a level of annual income is passed, the association becomes negative. On the other hand, it seems that income has positive effects on life satisfaction even in higher income classes. Second, this relationship can be studied through a model allowing a continuum of regimes, revealing the importance of the individual heterogeneity even in a non-linear environment.

This study suggests the non-linear examination of the relationship between income and subjective well-being measures using data from other countries and exploring the non-linear dynamics in various groups, including gender, age and regions among others. In addition, the valuation of public goods can be included in the analysis, as air quality, controlling additionally for meteorological data. In addition, important insights will be gained by additional comparisons between the life satisfaction approach and traditional methods, such as stated and preference methods, choice modelling and others. Another area for future research refers on improvements of the LSA. One major issue is the need for more precise estimates of the income effect on well-being measures, as it has been mentioned in the introduction part.

In a political economy sense, the results of this study further suggest that policy makers should concentrate upon economic factors, especially for those who belong to low income classes, while other determinants are important for the people's happiness when they belong to high income classes. Moreover, further research regarding the health status, job status and marital status can be applied, as income plays a more important role for widowed, divorced unemployed and individuals with health problems. This will help policy makers to consider additional factors, when they design policies improving the well-being of the divorced and 
widowed people, the unemployed and the old aged people, which the latter is characterised by the retirement status and for those who have poor health status.

\section{Acknowledgements}

This work was based on data from the British Household Panel Survey, Waves 1-18, 19912009: Conditional Access, Local Authority Districts, produced by the Institute for Social and Economic Research (ISER) at the University of Essex, sponsored by the Economic and Social Research Council (ESRC), and supplied by the UK Data Archive. The data are the copyright of ISER. The use of the data in this work does not imply the endorsement of ISER, ESRC or the UK Data Archive in relation to the interpretation or analysis of the data.

The authors would like to thank the anonymous reviewers for their valuable comments, suggestions and constructive comments that greatly contributed to the improvement of the quality of this paper. Any remaining errors or omissions remain the responsibility of the author. 


\section{References}

Aslanidis, N. and Xepapadeas, A. (2008) 'Regime switching and the shape of the emissionincome relationship', Economic Modelling, Vol. 25, No. 4, pp. 731-739.

Blanchflower D.G. and Oswald, A.J. (2007) 'Hypertension and Happiness across Nations', Journal of Health Economics, Vol. 27, No. 2, pp. 218-233.

Becchetti, L., Corrado, L. and Rossetti, F. (2009) 'Easterlin-types and Frustrated Achievers: The Heterogeneous Effects of Income Changes on Life Satisfaction', CWPE 0816.

Brereton, F., Clinch, J. P. and Ferreira, S. (2008) 'Happiness, geography and the environment', Ecological Economics, Vol. 65, No. 2, pp. 386-396.

Chevalier, A. and Giovanis, E. (2012) 'Valuing Air Pollution in Britain. For Presentation in 15th IZA European Summer School in Labor Economics', April 23-29, Buch/Ammersee, Germany.

Clark, A.E. and Oswald, A.J. (1994) 'Unhappiness and Unemployment', The Economic Journal, Vol. 104, No. 424, pp. 648-659.

Clark, A. (2003) 'Inequality-aversion and income mobility: A direct test', Working Paper No. 2003-11, Département et Laboratoire d'Économie Théorique Appliquée (DELTA).

Clark, A.E., Etilé, F., Postel-Vinay, F., Senik, C. and Van der Straeten, K. (2005) 'Heterogeneity in reported well-being: Evidence from twelve European countries', The Economic Journal, Vol. 115, No. 502, pp. 118-132.

Crouchley, R. and Oskrochi, G. (2001) 'A random effects treatment of dropout in the multispell multi-state labour market panel data of the BHPS', Working Paper 2001-02 of the Centre for Applied Statistics, Lancaster University.

Cummins, A. (2012) 'The determinants of happiness', International Journal of Happiness and Development, Vol. 1, No. 1, pp. 86-101.

Di Tella, R., MacCulloch, R.J. and Oswald, A.J. (2003) 'The Macroeconomics of Happiness', The Review of Economics and Statistics, Vol. 85, No. 4, pp. 809-827.

Diener, E. and Larsen, R. J. (1984) 'Temporal stability and cross-situational consistency of affective, behavioral, and cognitive responses', Journal of Personality and Social Psychology, Vol. 47, No. 4, pp. 871-883.

Diener, E., Emmons, R. A., Larsen, R. J. and Griffin, S. (1985) 'The satisfaction with life scale', Journal of Personality Assessment, Vol. 49, No. 1, pp. 71-75.

Easterlin, R. A. (1974) 'Does economic growth improve the human lot? Some empirical evidence', in David, P.A. and Reder, M.W. (Eds.), Nations and households in economic growth: Essays in honour of Moses Abramovitz. New York: Academic Press, pp. 89-125.

Easterlin, R.A. (2001) 'Income and Happiness: Towards a Unified Theory', The Economic Journal, Vol. 111, No. 473, pp. 465-484.

Eitrheim, O. And Teräsvirta, T. (1996) 'Testing the adequacy of smooth transition autoregressive models', Journal of Econometrics, Vol. 74, No. 1, pp. 59-75.

Fornell, C. and Larcker, D. F. (1981) 'Evaluating Structural Equation Models with Unobservable Variables and Measurement Error', Journal of Marketing Research, Vol. 18, No. 1, pp. 39-50.

Frijters, P. and van Praag, B.M.S. (1998) 'The effects of climate on welfare and wellbeing in Russia', Climatic Change, Vol. 39, No. 1, pp. 61-81.

Frijters, P., Haisken-Denew, J.P. and Shields, M.A. (2004) 'Money Does Matter! Evidence from Increasing Real Incomes and Life Satisfaction in East Germany Following Reunification', American Economic Review, Vol. 94, No. 3, pp. 730-740.

Frijters, P., Geishecker, I., Haisken-Denew, J.P. and Shields, M.A. (2006) 'Can the Large Swings in Russian Life Satisfaction be Explained byUps and Downs in Real Incomes?' Scandinavian Journal of Economics, Vol. 108, No. 3, pp. 433-458. 
Gardner, J. and Oswald, A.J. (2006) 'Do Divorcing Couples Become Happier by Breaking Up?' Journal of the Royal Statistical Society Series A, Vol. 169, No. 2, pp. 319-336.

Giovanis, E. (2012) 'Environmental Kuznets Curve and Air Pollution in City of London: Evidence from new Panel Smoothing Transition Regressions', International Journal of Pure and Applied Mathematics, Vol. 79, No. 3, pp. 393-404.

Giovanis, E. (2014) 'Relationship between Well-Being and Recycling Rates: Evidence from Life Satisfaction Approach in Britain', Journal of Environmental Economics and Policy, Vol. 3, No. 2, pp. 201-214.

Gonzalez, A., Teräsvirta, T.D. and van Dijk, D. (2005) 'Panel Smooth Transition Regression Models', SSE/EFI Working Paper Series in Economics and Finance, No. 604, August.

Granger, C.W.J. and Terasvirta, T. (1993) Modelling Non-linear Economic Relationships, Oxford: Oxford University Press, UK.

Gove, W.R., Style, C.B. and Hughes, M. (1990) 'The effect of marriage on the well-being of adults: a theoretical analysis', Journal of Family Issues, Vol. 11, No. 1, pp. 4-35.

Hancock, G.R. and Mueller, R.O. (2006) Structural equation modeling: A second course. Greenwich, CT: Information Age Publishing, Inc, USA.

Howell, R. T. and Howell, C. J. (2008) 'The relation of economic status to subjective wellbeing in developing countries: A meta-analysis', Psychological Bulletin, Vol. 134, No. 4, pp. 536-560.

$\mathrm{Hu}, \mathrm{L}$. and Bentler, P.M. (1999) 'Cutoff criteria for fit indexes in covariance structure analysis: Conventional criteria versus new alternatives', Structural Equation Modeling: A Multidisciplinary Journal, Vol. 6, No. 1, pp. 1-55.

Jack, B. and Clarke, A. (1998) 'The purpose and use of questionnaires in research', Professional Nurse Vol. 14, No. 3, pp. 176-179.

Jansen, E. S. and Terasvirta, T. (1996). 'Testing Parameter Constancy and Super Exogeneity in Econometric Equations', Oxford Bulletin of Economics and Statistics, Vol. 58, No. 4, pp. 735-763.

Kahneman, D. and Deaton, A. (2010) 'High income improves evaluation of life but not emotional well-being', Proceedings of the National Academy of Sciences, Vol. 207, No. 38, pp. 16489-16493.

Lucas, R. E., Clark, A. E., Georgellis, Y. and Diener, E. (2003) 'Reexamining adaptation and the set point model of happiness: Reactions to changes in marital status', Journal of Personality and Social Psychology, Vol. 84, No. 3, pp. 527-539.

Lucas, R. E. and Clark, A. E. (2006) 'Do people really adapt to marriage?' Journal of Happiness Studies, Vol. 7, No. 4, pp. 405-426.

Lucas, R. E. (2007). 'Long-term disability is associated with lasting changes in subjective wellbeing: Evidence from two nationally representative longitudinal studies', Journal of Personality and Social Psychology, Vol. 92, No. 4, pp. 717-730.

Lucas, R. E. and Schimmack, U. (2009) 'Income and well-being: How big is the gap between the rich and the poor?' Journal of Research in Personality, Vol. 43, No. 1, pp. 75-78.

Luukkonen, R., Saikkonen, P. and Teräsvirta, T. (1988) 'Testing linearity against smooth transition autoregressive models', Biometrika, Vol. 75, No. 3, pp. 491-499.

Marks, G.N. and Fleming, N. (1999) 'Influences and Consequences of Well-being among Australian Young People: 1980-1995', Social Indicators Research, Vol. 46, No. 3, pp. 301323.

Mayraz, G., Wagner, G.G. and Schupp, J. (2009) 'Life Satisfaction and Relative Income: Perceptions and Evidence', Discussion Paper No. 4390, IZA.

Pischke, J.S. (2011) 'Money and Happiness: Evidence from the Industry Wage Structure', Discussion Paper No. 5705, IZA. 
Rattray, J. and Jones, M.C. (2007) 'Essential elements of questionnaire design and development', Journal of Clinical Nursing, Vol. 16, No. 2, pp. 234-243.

Rehdanz, K. and Maddison, D. (2008) 'Local environmental quality and life-satisfaction in Germany’, Ecological Economics, Vol. 64, No. 4, pp. 787-797.

Sandvik E., Diener, E. and Seidlitz, L. (1993) 'Subjective Well-Being: The Convergence and Stability of Self-Report and Non-Self-Report Measures', Journal of Personality, Vol. 61, No. 3, pp. 317-342.

Shields, M. and Wailoo, A. (2002) 'Exploring the determinants of unhappiness for ethnic minority men in Britain', Scottish Journal of Political Economy, Vol. 49, No. 4, pp. 445466.

Stutzer, A. and Frey, B.S. (2006) 'Does Marriage Make People Happy, or Do Happy People Get Married?' Journal of Socio-Economics, Vol. 35, No. 2, pp. 326-347.

Teräsvirta, T. (1994). Specification, estimation, and evaluation of smooth transition autoregressive models. Journal of the American Statistical Association, Vol. 89, No. 425, pp. 208-218.

Uhlaner, C. J. (1989) 'Relational Goods and Participation: Incorporating Sociability into a Theory of Rational Action', Public Choice, Vol. 62, No.3, pp. 253-285.

Van den Berg, B. and Ferrer-i-Carbonell, A. (2005) 'The well-being of informal caregivers: A monetary valuation of informal care', paper for iHEA 2005, Barcelona, Spain.

Van Dijk, D., Teräsvirta, T. and Franses, P.H. (2002) 'Smooth transition autoregressive models - a survey of recent developments', Econometric Reviews, Vol. 21, No. 1, pp. 1-47.

Van Praag, B.M.B. and Ferrer-i-Carbonell, A. (2004) Happiness quantified: A satisfaction calculus approach, Oxford: Oxford University Press, UK.

Welsch, H. (2006) 'Environment and happiness: Valuation of air pollution using life satisfaction data', Ecological Economics, Vol. 58, No. 4, pp. 801-813.

Welsch, H. (2007) 'Environmental welfare analysis: A life satisfaction approach', Ecological Economics, Vol. 62, Nos. 3-4, pp. 544-551.

Winkelmann, L. and Winkelmann, R. (1998) 'Why Are the Unemployed So Unhappy?' Evidence from Panel Data. Economica, Vol. 65, No. 257, pp. 1-15.

Zimmermann A.C. and Easterlin, A.E. (2006). Happily ever after? Cohabitation, marriage, divorce, and happiness in Germany. Population and Development Review, Vol. 32, No. 3, pp. 511-528. 
Table 1. Reliability, Validity and Goodness of fit tests

\begin{tabular}{cc}
\hline Indices & Value \\
\hline Cronbach's alpha & 0.8754 \\
Composite Reliability (CR) & 0.7491 \\
Average Variance Extracted (AVE) & 0.6893 \\
CFI & 0.998 \\
TLI & 0.983 \\
RMSEA & 0.0004 \\
RMSR & 0.0002 \\
\hline
\end{tabular}

Table 2. Non Linearity Test

\begin{tabular}{ccc}
\hline Life satisfaction & Happiness & $\begin{array}{c}\text { Depress and daily } \\
\text { activities enjoyment }\end{array}$ \\
\hline $26.31^{* * *}$ & $15.68^{* * * *}$ & $19.03^{* * *}$ \\
$(0.000)$ & $(0.0002)$ & $(0.0001)$ \\
\hline p-values between brackets, ${ }^{* * *}$ indicates significance at $1 \%$ level
\end{tabular}


Table 3. Logistic and Exponential PSTR results

\begin{tabular}{|c|c|c|c|c|c|c|}
\hline \multirow[b]{2}{*}{ Coefficients } & \multicolumn{3}{|c|}{ Logistic } & \multicolumn{3}{|c|}{ Exponential } \\
\hline & $\begin{array}{c}\text { Life } \\
\text { satisfaction }\end{array}$ & Happiness & $\begin{array}{c}\text { Depress and } \\
\text { enjoyment } \\
\text { with daily } \\
\text { activities }\end{array}$ & $\begin{array}{c}\text { Life } \\
\text { satisfaction }\end{array}$ & Happiness & $\begin{array}{c}\text { Depress and } \\
\text { enjoyment } \\
\text { with daily } \\
\text { activities }\end{array}$ \\
\hline Linear Regime & -0.0094 & -0.0208 & -0.0134 & $0.0324 * * *$ & $0.0058 * *$ & $0.0103 * *$ \\
\hline$\left(\beta_{0}\right)$ & $(0.0119)$ & $(0.0312)$ & $(0.0166)$ & $(0.0054)$ & $(0.0027)$ & $(0.0049)$ \\
\hline Non Linear Regime & $0.0352 * * *$ & $0.0241 * *$ & $0.0183 * *$ & $0.0056^{* *}$ & $-0.0088 * *$ & $-0.0136^{* *}$ \\
\hline$\left(\beta_{I}\right)$ & $(0.0132)$ & $(0.0112)$ & $(0.0091)$ & $(0.0024)$ & $(0.0043)$ & $(0.0061)$ \\
\hline Sum of Linear and & $0.0258 *$ & $0.0033^{*} *$ & $0.0049 * *$ & $0.0380 * * *$ & $-0.0030 * *$ & $-0.0033 * *$ \\
\hline \multicolumn{7}{|l|}{$\begin{array}{c}\text { Coefficients } \\
\left(\beta_{0}+\beta_{1}\right)\end{array}$} \\
\hline \multirow{2}{*}{$\begin{array}{l}\text { Location Parameter } \\
\text { (c) }\end{array}$} & $7.708 * * *$ & $7.387 * * *$ & $7.093 * * *$ & $9.660 * * *$ & $9.157 * * *$ & $9.123 * * *$ \\
\hline & $(0.4772)$ & $(0.2411)$ & $(0.3076)$ & $(0.5692)$ & $(0.6271)$ & $(0.6583)$ \\
\hline \multirow{2}{*}{$\begin{array}{c}\text { Slope Parameter } \\
(\gamma)\end{array}$} & $0.9036^{* *}$ & $1.1782 * *$ & $1.2550 * *$ & $0.9567 * * *$ & $1.2392 *$ & $1.2750 * *$ \\
\hline & $(0.3898)$ & $(0.4869)$ & $(0.4981)$ & $(0.2512)$ & $(0.6524)$ & $(0.5890)$ \\
\hline \multirow[t]{2}{*}{ Income*single } & $0.0885 * * *$ & $0.0667 * * *$ & $0.0423 * * *$ & $0.0881 * * *$ & $0.0662 * * *$ & $0.0420 * * *$ \\
\hline & $(0.0129)$ & $(0.0114)$ & $(0.0109)$ & $(0.0128)$ & $(0.0114)$ & $(0.0109)$ \\
\hline \multirow[t]{2}{*}{ Income* widowed } & $0.0924 * * *$ & $0.0288 * *$ & $0.0240 * *$ & $0.0921 * * *$ & $0.0281 * *$ & $0.0237 * *$ \\
\hline & $(0.0164)$ & $(0.0139)$ & $(0.0118)$ & $(0.0163)$ & $(0.0138)$ & $(0.0115)$ \\
\hline \multirow[t]{2}{*}{ Income* divorced } & $0.0996 * * *$ & $0.0468 * * *$ & $0.0389 *$ & $0.0997 * * *$ & $0.0479 * * *$ & $0.0385^{*}$ \\
\hline & $(0.0254)$ & $(0.0176)$ & $(0.0206)$ & $(0.0253)$ & $(0.0176)$ & $(0.0204)$ \\
\hline \multirow[t]{2}{*}{ Income*unemployed } & $0.827 * * *$ & $0.556^{* * *}$ & $0.341 * *$ & $0.825 * * *$ & $0.541 * * *$ & $0.340^{* *}$ \\
\hline & $(0.113)$ & $(0.0142)$ & $(0.0157)$ & $(0.115)$ & $(0.0133)$ & $(0.0157)$ \\
\hline \multirow[t]{2}{*}{ Income*retired } & $0.426^{*}$ & $0.335^{*}$ & $0.447 * *$ & $0.424^{*}$ & $0.339 *$ & $0.448 * *$ \\
\hline & $(0.245)$ & $(0.197)$ & $(0.213)$ & $(0.244)$ & $(0.198)$ & $(0.213)$ \\
\hline \multirow[t]{2}{*}{ Income $*$ first degree } & 0.0073 & 0.0068 & 0.0188 & 0.0073 & 0.0066 & 0.0189 \\
\hline & $(0.0143)$ & $(0.0110)$ & $(0.0263)$ & $(0.0142)$ & $(0.0110)$ & $(0.0265)$ \\
\hline \multirow[t]{2}{*}{ Income*A level } & $0.0261 * * *$ & $0.0173 * *$ & $0.0253 * *$ & $0.0262 * * *$ & $0.0176 * *$ & $0.0256 * *$ \\
\hline & $(0.0086)$ & $(0.0084)$ & $(0.0121)$ & $(0.0086)$ & $(0.0087)$ & $(0.0122)$ \\
\hline \multirow[t]{2}{*}{ Income*poor health } & $-0.1543 * *$ & $-0.1082 * *$ & $-0.1290 * *$ & $0.1548 * *$ & $-0.1082 * *$ & $-0.1291 * *$ \\
\hline & $(0.0683)$ & $(0.0432)$ & $(0.0513)$ & $(0.0684)$ & $(0.0435)$ & $(0.0513)$ \\
\hline \multirow{2}{*}{$\begin{array}{l}\text { Income*very good } \\
\text { health }\end{array}$} & $-0.5492 * * *$ & $-0.4505 * * *$ & $-0.4781 * * *$ & $-0.5494 * * *$ & $-0.4506 * * *$ & $-0.4781 * * *$ \\
\hline & $(0.0026)$ & $(0.0033)$ & $(0.0022)$ & $(0.0026)$ & $(0.0032)$ & $(0.0022)$ \\
\hline No. Obs & 133,466 & 203,515 & 202,916 & 133,466 & 203,515 & 202,916 \\
\hline RSS & $10,781.093$ & $17,599.502$ & $16,150.044$ & $10,779.584$ & $17,406.906$ & $16,154.913$ \\
\hline AIC & 3,080 & 5,138 & 5,040 & 3,047 & 5,139 & 5,039 \\
\hline $\mathrm{BIC}$ & 3,126 & 5,188 & 5,086 & 3,122 & 5,183 & 5,083 \\
\hline No remaining non- & 11.883 & 11.891 & 9.058 & 12.151 & 12.256 & 11.096 \\
\hline linearity LM test & {$[0.2248]$} & {$[0.2253]$} & {$[0.2538]$} & {$[0.2188]$} & {$[0.2122]$} & {$[0.2246]$} \\
\hline
\end{tabular}

Standard errors between brackets, p-values between square brackets, clustered standard errors on local authority districts

$* * *, * *$ and $*$ indicate significance at $1 \%, 5 \%$ and $10 \%$ level 
Table 4. Power Parity of Income

\begin{tabular}{cc}
\hline Year & Value Change on Income \\
\hline 1991 & 73,800 \\
1992 & 76,200 \\
1993 & 78,200 \\
1994 & 79,100 \\
1995 & 81,100 \\
1996 & 84,300 \\
1997 & 86,450 \\
1998 & 87,750 \\
1999 & 88,750 \\
2000 & 90,900 \\
2001 & 91,900 \\
2002 & 94,300 \\
2003 & 96,350 \\
2004 & 99,150 \\
2005 & 102,000 \\
2006 & 104,700 \\
2007 & 107,700 \\
2008 & 110,800 \\
2009 & 113,000 \\
\hline
\end{tabular}


Table 5. Coefficients of the Control Variables from Logistic PSTR Model

\begin{tabular}{|c|c|c|c|c|c|c|c|}
\hline Variables & $\begin{array}{c}\text { Life } \\
\text { satisfaction }\end{array}$ & Happiness & $\begin{array}{c}\text { Depress and } \\
\text { enjoyment with } \\
\text { daily activities }\end{array}$ & Variables & $\begin{array}{c}\text { Life } \\
\text { satisfaction }\end{array}$ & Happiness & $\begin{array}{c}\text { Depress and } \\
\text { enjoyment with } \\
\text { daily activities } \\
\end{array}$ \\
\hline Age & $\begin{array}{c}-0.0266 * * * \\
(0.0009)\end{array}$ & $\begin{array}{c}-0.0181 * * * \\
(0.0008)\end{array}$ & $\begin{array}{c}-0.0187 * * * \\
(0.0011)\end{array}$ & $\begin{array}{l}\text { Diff-Max-Min } \\
\text { Temperature }\end{array}$ & $\begin{array}{l}0.0083 * * \\
(0.0037)\end{array}$ & $\begin{array}{l}0.0034 * * \\
(0.0015)\end{array}$ & $\begin{array}{l}0.0032 * \\
(0.0017)\end{array}$ \\
\hline Age squared & $\begin{array}{c}0.00030 * * * \\
(9.95 \mathrm{e}-06)\end{array}$ & $\begin{array}{c}0.00018 * * * \\
(8.72 \mathrm{e}-06)\end{array}$ & $\begin{array}{c}0.00022 * * * \\
(8.41 \mathrm{e}-06)\end{array}$ & Wind Speed & $\begin{array}{l}-0.0022 \\
(0.0030)\end{array}$ & $\begin{array}{l}-0.0052 \\
(0.0036)\end{array}$ & $\begin{array}{l}-0.0091 \\
(0.0088)\end{array}$ \\
\hline Household size & $\begin{array}{c}-0.0249 \\
(0.0042)^{* * *}\end{array}$ & $\begin{array}{c}-0.0175 \\
(0.0022)^{* * *}\end{array}$ & $\begin{array}{c}-0.0182 \\
(0.0023)^{* * *}\end{array}$ & Precipitation & $\begin{array}{c}0.0023 * * \\
(0.0011)\end{array}$ & $\begin{array}{c}0.0013 * \\
(0.00068)\end{array}$ & $\begin{array}{c}0.0022 \\
(0.0035)\end{array}$ \\
\hline Marital Status (ref= married) & & & & $\begin{array}{l}\text { Education } \\
\text { (ref=Higher } \\
\text { degree) }\end{array}$ & & & \\
\hline Marital Status (Single) & $\begin{array}{c}-0.0245 \\
(0.0025)^{* * *}\end{array}$ & $\begin{array}{l}-0.0146 \\
(0.0273)\end{array}$ & $\begin{array}{l}-0.0119 \\
(0.0249)\end{array}$ & $\begin{array}{l}\text { Education Level } \\
\text { (First Degree) }\end{array}$ & $\begin{array}{l}-0.0162 \\
(0.0224)\end{array}$ & $\begin{array}{l}-0.0062 \\
(0.0901)\end{array}$ & $\begin{array}{l}-0.0075 \\
(0.0293)\end{array}$ \\
\hline Marital Status (Widowed) & $\begin{array}{c}-0.2847 \\
(0.0218)^{* * *}\end{array}$ & $\begin{array}{c}-0.0828 * * * \\
(0.0202)\end{array}$ & $\begin{array}{c}-0.0894 * * * \\
(0.0232)\end{array}$ & $\begin{array}{l}\text { Education Level } \\
\text { (Teaching, HNC) }\end{array}$ & $\begin{array}{c}-0.0473 * * \\
(0.0215)\end{array}$ & $\begin{array}{l}-0.0364 \\
(0.0270)\end{array}$ & $\begin{array}{l}-0.0377 \\
(0.0273)\end{array}$ \\
\hline Marital Status (Divorced) & $\begin{array}{c}-0.4164 \\
(0.0803)^{* * *}\end{array}$ & $\begin{array}{c}-0.0659 * * * \\
(0.0182)\end{array}$ & $\begin{array}{c}-0.0554 * * \\
(0.0237)\end{array}$ & $\begin{array}{l}\text { Education Level } \\
\text { (A Level) }\end{array}$ & $\begin{array}{c}-0.0516 * * * \\
(0.0168)\end{array}$ & $\begin{array}{c}-0.0147 * * \\
(0.0071)\end{array}$ & $\begin{array}{l}-0.0151 * * \\
(0.0073)\end{array}$ \\
\hline Job Status (ref= employed) & & & & $\begin{array}{c}\text { Tenure (ref }=\text { owned } \\
\text { outright) }\end{array}$ & & & \\
\hline Job Status (Unemployed) & $\begin{array}{c}-0.1605^{* * * *} \\
(0.0423)\end{array}$ & $\begin{array}{c}-0.1210 * * * \\
(0.0244)\end{array}$ & $\begin{array}{c}-0.1827 * * * \\
(0.0495)\end{array}$ & $\begin{array}{l}\text { Tenure house } \\
\text { (Owned with } \\
\text { mortgage) }\end{array}$ & $\begin{array}{c}-0.0582 * * * \\
(0.0163)\end{array}$ & $\begin{array}{c}-0.0257 * * * \\
(0.0091)\end{array}$ & $\begin{array}{c}-0.0301 * * * \\
(0.0051)\end{array}$ \\
\hline Job Status (Retired) & $\begin{array}{c}-0.2651 * * \\
(0.1283)\end{array}$ & $\begin{array}{c}-0.1161 * * * \\
(0.0231)\end{array}$ & $\begin{array}{c}-0.1357 * * * \\
(0.0344)\end{array}$ & $\begin{array}{l}\text { Tenure house } \\
\text { (Rented LA) }\end{array}$ & $\begin{array}{c}-0.2412 * * \\
(0.1154)\end{array}$ & $\begin{array}{c}-0.0622 * * * \\
(0.0124)\end{array}$ & $\begin{array}{c}-0.0863 * * \\
(0.0431)\end{array}$ \\
\hline Average Temperature & $\begin{array}{c}0.01010 * * \\
(0.0044)\end{array}$ & $\begin{array}{c}0.0112 * * \\
(0.0053)\end{array}$ & $\begin{array}{l}0.0081^{*} \\
(0.0044)\end{array}$ & $\begin{array}{l}\text { Health Status } \\
\text { (Very Poor) }\end{array}$ & $\begin{array}{c}-0.9894 * * * \\
(0.0226)\end{array}$ & $\begin{array}{c}-0.8505 * * * \\
(0.0432)\end{array}$ & $\begin{array}{c}-0.9281 * * * \\
(0.0325)\end{array}$ \\
\hline
\end{tabular}

***,** and $*$ indicate significance at $1 \%, 5 \%$ and $10 \%$ level 
Table 6. Coefficients of the Control Variables from Exponential PSTR Model

\begin{tabular}{|c|c|c|c|c|c|c|c|}
\hline Variables & $\begin{array}{c}\text { Life } \\
\text { satisfaction }\end{array}$ & Happiness & $\begin{array}{c}\text { Depress and } \\
\text { enjoyment with } \\
\text { daily activities }\end{array}$ & Variables & $\begin{array}{c}\text { Life } \\
\text { satisfaction }\end{array}$ & Happiness & $\begin{array}{c}\text { Depress and } \\
\text { enjoyment } \\
\text { with daily } \\
\text { activities }\end{array}$ \\
\hline Age & $\begin{array}{c}-0.0266 * * * \\
(0.0009)\end{array}$ & $\begin{array}{c}-0.0181 * * * \\
(0.0008)\end{array}$ & $\begin{array}{c}-0.0186 * * * \\
(0.0011)\end{array}$ & $\begin{array}{l}\text { Diff-Max-Min } \\
\text { Temperature }\end{array}$ & $\begin{array}{l}0.0082 * * \\
(0.0037)\end{array}$ & $\begin{array}{l}0.0038^{* *} \\
(0.0016)\end{array}$ & $\begin{array}{l}0.0032^{*} \\
(0.0017)\end{array}$ \\
\hline Age squared & $\begin{array}{c}0.00030 * * * \\
(9.95 \mathrm{e}-06)\end{array}$ & $\begin{array}{c}0.00019 * * * \\
(8.78 \mathrm{e}-06)\end{array}$ & $\begin{array}{c}0.00022^{* * *} \\
(8.43 \mathrm{e}-06)\end{array}$ & Wind Speed & $\begin{array}{l}-0.0025 \\
(0.0032)\end{array}$ & $\begin{array}{l}-0.0055 \\
(0.0036)\end{array}$ & $\begin{array}{l}-0.0093 \\
(0.0089)\end{array}$ \\
\hline Household size & $\begin{array}{c}-0.0254 \\
(0.0043)^{* * *}\end{array}$ & $\begin{array}{c}-0.0172 \\
(0.0021)^{* * *}\end{array}$ & $\begin{array}{c}-0.0178 \\
(0.0025)^{* * *}\end{array}$ & Precipitation & $\begin{array}{l}0.0024 * * \\
(0.0011)\end{array}$ & $\begin{array}{c}0.0013 * \\
(0.00067)\end{array}$ & $\begin{array}{c}0.0021 \\
(0.0035)\end{array}$ \\
\hline Marital Status (ref= married) & & & & $\begin{array}{l}\text { Education } \\
\text { (ref=Higher } \\
\text { degree) }\end{array}$ & & & \\
\hline Marital Status (Single) & $\begin{array}{c}-0.0257 \\
(0.0023)^{* * *}\end{array}$ & $\begin{array}{c}-0.0144 \\
(0.0277)\end{array}$ & $\begin{array}{l}-0.0117 \\
(0.0253)\end{array}$ & $\begin{array}{l}\text { Education Level } \\
\text { (First Degree) }\end{array}$ & $\begin{array}{l}-0.0135 \\
(0.0214)\end{array}$ & $\begin{array}{l}-0.0069 \\
(0.0902)\end{array}$ & $\begin{array}{l}-0.0078 \\
(0.0301)\end{array}$ \\
\hline Marital Status (Widowed) & $\begin{array}{c}-0.2909 \\
(0.0212)^{* * *}\end{array}$ & $\begin{array}{c}-0.0842 * * * \\
(0.0203)\end{array}$ & $\begin{array}{c}-0.0892 * * * \\
(0.0231)\end{array}$ & $\begin{array}{l}\text { Education Level } \\
\text { (Teaching, HNC) }\end{array}$ & $\begin{array}{c}-0.0489 * * \\
(0.0235)\end{array}$ & $\begin{array}{l}-0.0383 \\
(0.0902)\end{array}$ & $\begin{array}{l}-0.0363 \\
(0.0270)\end{array}$ \\
\hline Marital Status (Divorced) & $\begin{array}{c}-0.4156 \\
(0.0812)^{* * *}\end{array}$ & $\begin{array}{c}-0.0657 * * * \\
(0.0183)\end{array}$ & $\begin{array}{c}-0.0560 * * \\
(0.0235)\end{array}$ & $\begin{array}{l}\text { Education Level } \\
\text { (A Level) }\end{array}$ & $\begin{array}{c}-0.0528 * * * \\
(0.0169)\end{array}$ & $\begin{array}{c}-0.0154 * * \\
(0.0075)\end{array}$ & $\begin{array}{c}-0.0147 * * \\
(0.0072)\end{array}$ \\
\hline Job Status (ref=employed) & & & & $\begin{array}{c}\text { Tenure }(\mathrm{ref}=\text { owned } \\
\text { outright })\end{array}$ & & & \\
\hline Job Status (Unemployed) & $\begin{array}{c}-0.1589 * * * \\
(0.0459)\end{array}$ & $\begin{array}{c}-0.1228 * * * \\
(0.0246)\end{array}$ & $\begin{array}{c}-0.1787 * * * \\
(0.0491)\end{array}$ & $\begin{array}{l}\text { Tenure house } \\
\text { (Owned with } \\
\text { mortgage) }\end{array}$ & $\begin{array}{c}-0.0577 * * * \\
(0.0162)\end{array}$ & $\begin{array}{c}-0.0262 * * * \\
(0.0093)\end{array}$ & $\begin{array}{c}-0.0309 * * * \\
(0.0052)\end{array}$ \\
\hline Job Status (Retired) & $\begin{array}{c}-0.2532 * * \\
(0.1125)\end{array}$ & $\begin{array}{c}-0.1156 * * * \\
(0.0230)\end{array}$ & $\begin{array}{c}-0.1374 * * * \\
(0.0349)\end{array}$ & $\begin{array}{l}\text { Tenure house } \\
\text { (Rented LA) }\end{array}$ & $\begin{array}{c}-0.2380 * * \\
(0.1045)\end{array}$ & $\begin{array}{c}-0.0615 * * * \\
(0.0120)\end{array}$ & $\begin{array}{c}-0.0878 * * \\
(0.0433)\end{array}$ \\
\hline Average Temperature & $\begin{array}{c}0.0109 * * \\
(0.0044)\end{array}$ & $\begin{array}{c}0.0114 * * \\
(0.0054)\end{array}$ & $\begin{array}{l}0.0082 * \\
(0.0044)\end{array}$ & $\begin{array}{l}\text { Health Status } \\
\text { (Very Poor) }\end{array}$ & $\begin{array}{c}-0.9892 * * * \\
(0.0226)\end{array}$ & $\begin{array}{c}-0.8506 * * * \\
(0.0432)\end{array}$ & $\begin{array}{c}-0.9281 * * * \\
(0.0327)\end{array}$ \\
\hline
\end{tabular}

$* * *, * *$ and $*$ indicate significance at $1 \%, 5 \%$ and $10 \%$ level 
Figure 1. Logistic PSTR $\beta_{0}+\beta_{1} G(\cdot)$ for Happiness

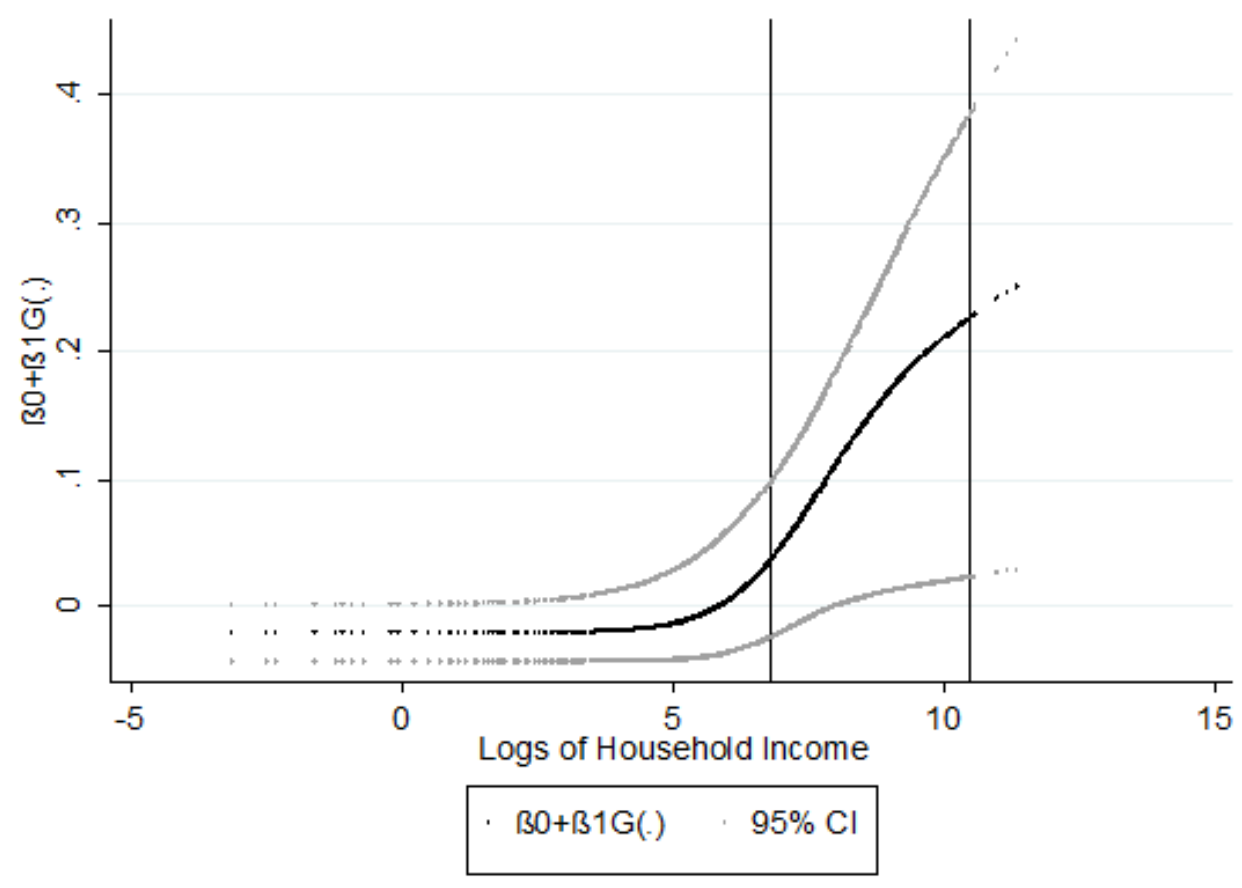

Figure 2. Logistic PSTR $\beta_{0}+\beta_{1} \mathrm{G}(\cdot)$ for Depression-Unhappy and enjoyment with daily activities

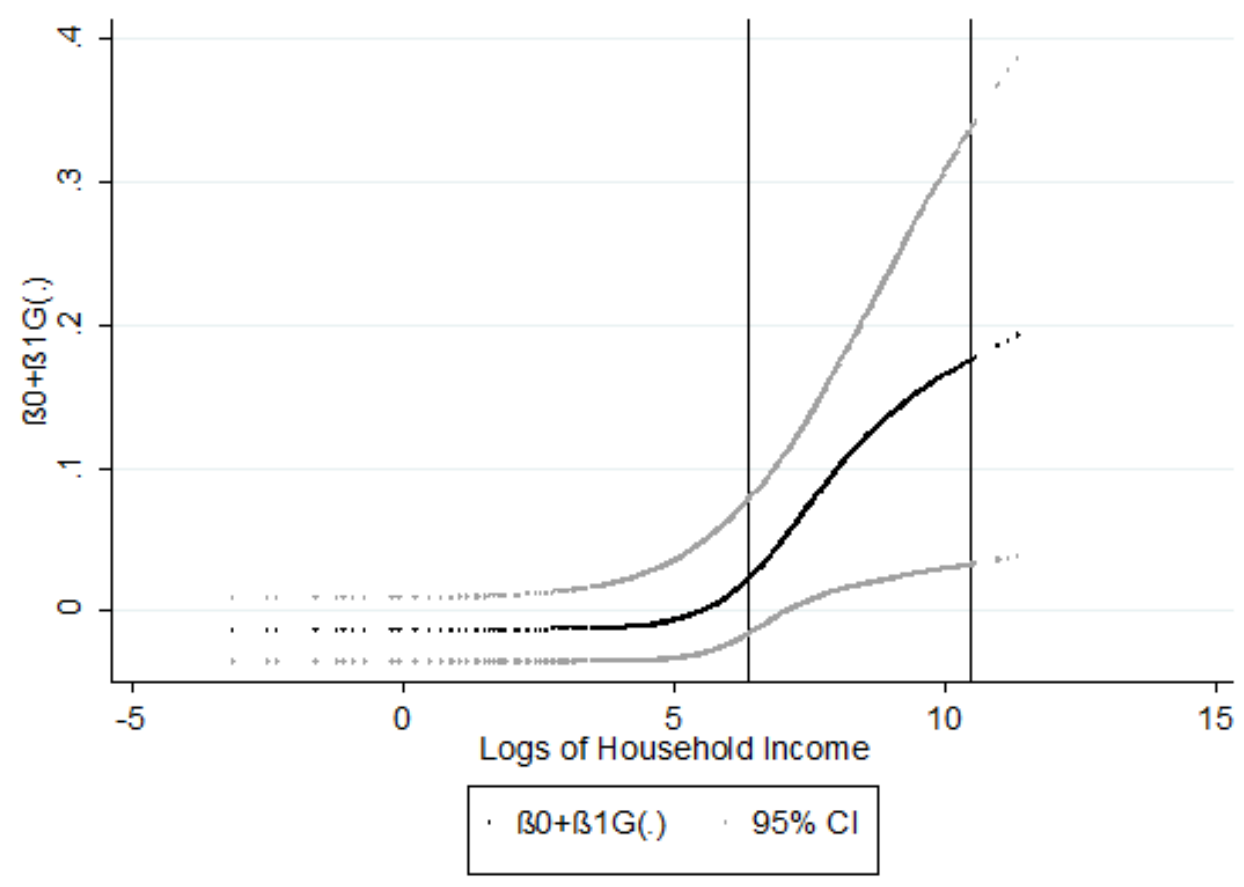


Figure 3. Logistic PSTR $\beta_{0}+\beta_{1} \mathrm{G}(\cdot)$ for Life Satisfaction

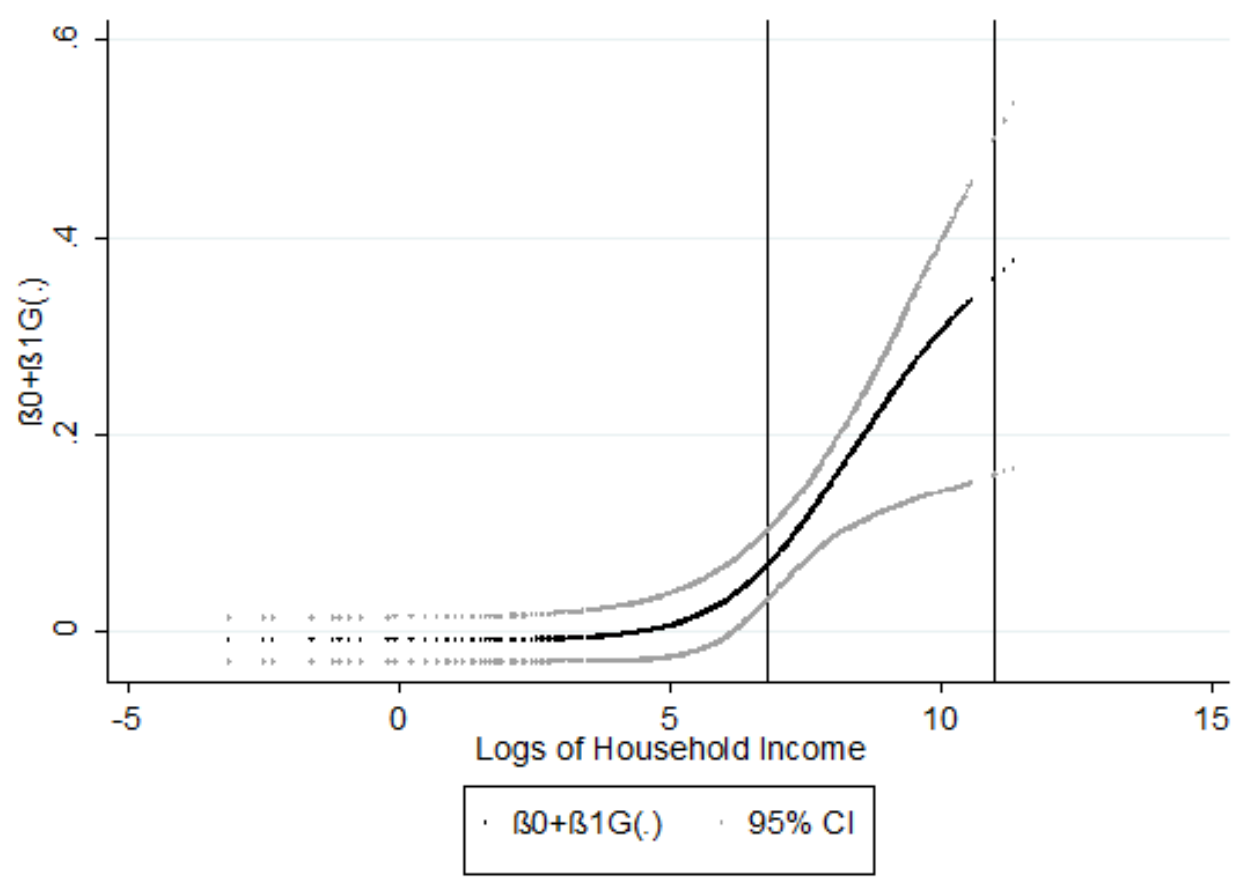

Figure 4. Exponential PSTR $\beta_{0}+\beta_{1} G(\cdot)$ for Happiness

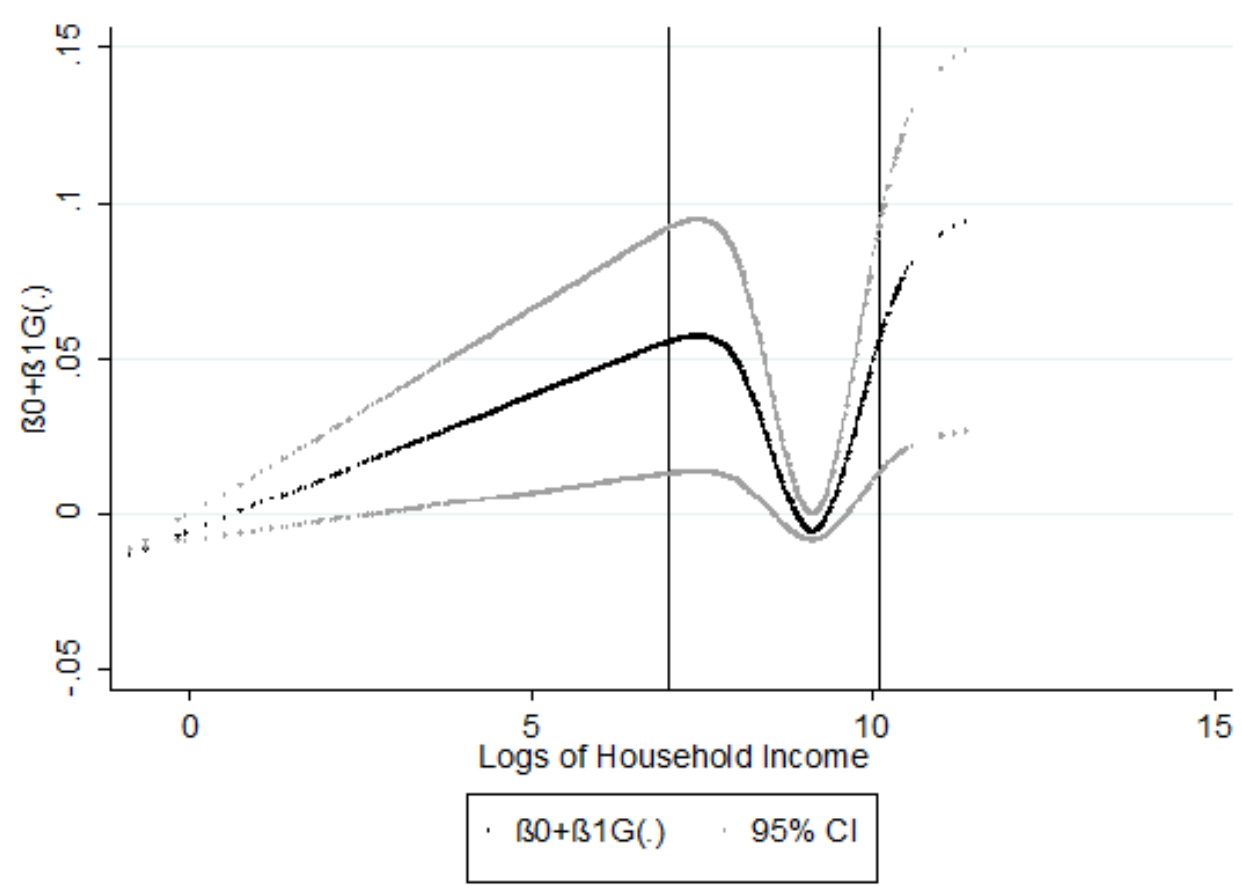


Figure 5. Exponential PSTR $\beta_{0}+\beta_{1} \mathrm{G}(\cdot)$ for Depression-Unhappy and enjoyment with daily activities

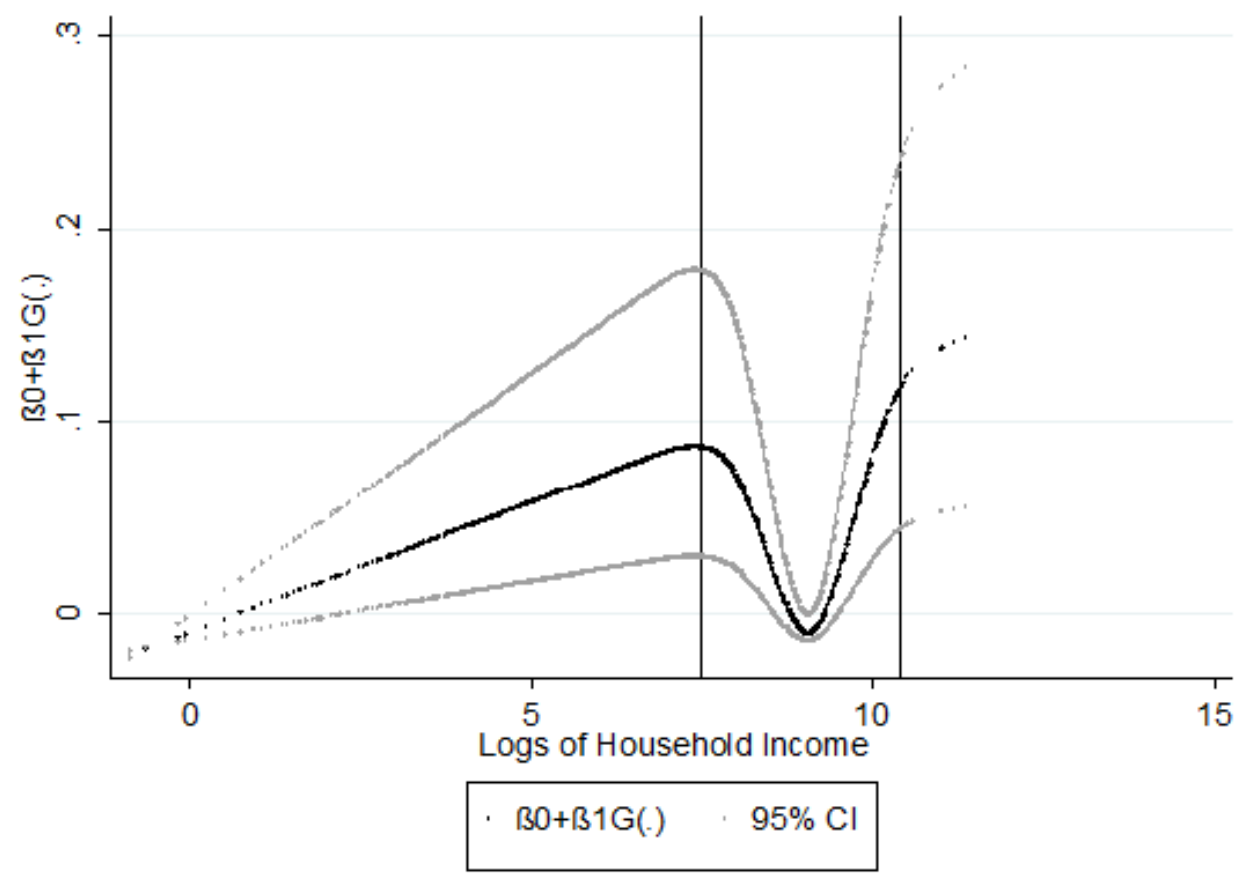

Figure 6. Exponential PSTR $\beta_{0}+\beta_{1} \mathrm{G}(\cdot)$ for Life Satisfaction

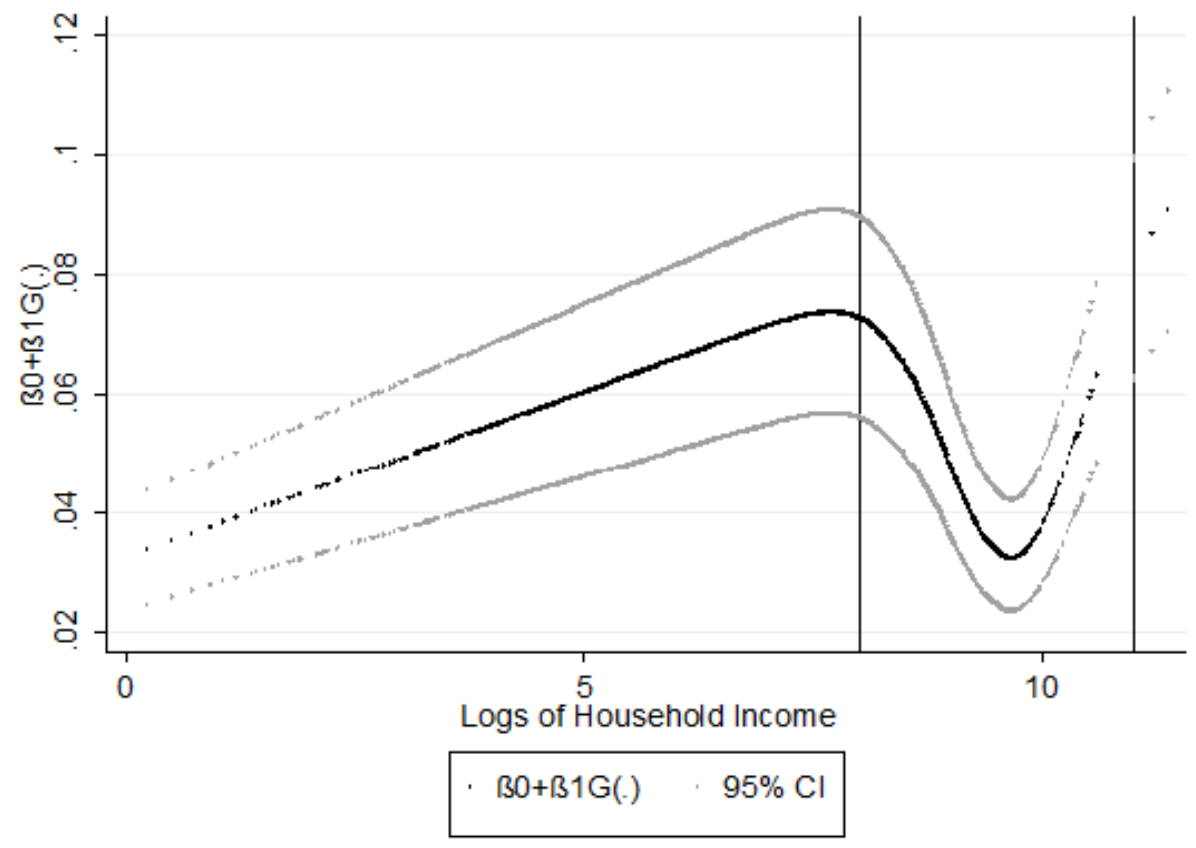

